\title{
Narrow-clawed crayfish in Finland: Aphanomyces astaci resistance and genetic relationship to other selected European and Asian populations
}

\author{
Japo Jussila ${ }^{1, *}$, Ivana Maguire ${ }^{2}$, Harri Kokko ${ }^{1}$, Vesa Tiitinen ${ }^{3}$ and Jenny Makkonen ${ }^{1}$ \\ ${ }^{1}$ Department of Environmental and Biological Sciences, University of Eastern Finland, P.O. Box 1627, 70210 Kuopio, Suomi-Finland \\ ${ }^{2}$ University of Zagreb, Faculty of Science, Department of Biology, Rooseveltov trg 6, Zagreb, Croatia \\ ${ }^{3}$ South Karelian Fisheries Advisory Center, Lappeenranta, Suomi-Finland
}

Received: 11 November 2019 / Accepted: 1 June 2020

\begin{abstract}
The narrow-clawed crayfish (Pontastacus leptodactylus) is an alien species in Finland with only a few populations reported from the southeastern region during the last century. We discovered a productive population in the lake Jängynjärvi, which is upstream from the previously reported wild narrow-clawed crayfish population in that region. Preliminary studies indicated that this population is not infected with Aphanomyces astaci. We collected narrow-clawed crayfish samples from the lake Jängynjärvi population for both infection challenge and genetic studies, in order to investigate possible $A$. astaci resistance among this Finnish population and to evaluate their phylogenetic position that would enable us to speculate different scenarios of distribution pathways or origin of the population. The infection studies indicated that the narrow-clawed crayfish in this population were more resistant against $A$. astaci infection (B haplogroup A. astaci) compared to the noble crayfish (Astacus astacus) from the lake Rytky in North Savo, while all crayfish of both species in the B haplogroup $A$. astaci challenged groups died within 58 days post-infection. Results of the phylogenetic reconstruction indicate that the lake Jängynjärvi narrow-clawed crayfish are closely related to narrow-clawed crayfish from the lake Bolshoye near Krasnoye, located on the White Sea island of Solovestky and also populations from Tyumen region, both in Russia. This could confirm previous speculations about introduction of the narrow-clawed crayfish from Russia into Finland or could indicate previous hydrological connection.
\end{abstract}

Keywords: Pontastacus leptodactylus / Astacus leptodactylus / crayfish plague / cytochrome I oxidase

Résumé - L'écrevisse à pattes grêles en Finlande: résistance à l'Aphanomyces astaci et relation génétique avec d'autres populations européennes et asiatiques. L'écrevisse à pattes grêles (Pontastacus leptodactylus) est une espèce exotique en Finlande, avec seulement quelques populations signalées dans la région sud-est au cours du siècle dernier. Nous avons découvert une population productive dans le lac Jängynjärvi, qui se trouve en amont de la population sauvage d'écrevisses à pinces étroites signalée précédemment dans cette région. Des études préliminaires ont indiqué que cette population n'est pas infectée par Aphanomyces astaci. Nous avons prélevé des échantillons d'écrevisses à pinces étroites dans la population du lac Jängynjärvi, à la fois pour des études sur le test de l'infection et des études génétiques, afin d'étudier la résistance possible à $A$. astaci dans cette population finlandaise et d'évaluer leur position phylogénétique, ce qui nous permettrait de spéculer sur différents scénarios de voies de diffusion ou d'origine de la population. Les études d'infection ont montré que les écrevisses à pinces étroites de cette population étaient plus résistantes à l'infection par $\mathrm{A}$. astaci (haplogroupe $\mathrm{B} \mathrm{A}$. astaci) que les écrevisses nobles (Astacus astacus) du lac Rytky dans le nord du Savo, tandis que toutes les écrevisses des deux espèces de l'haplogroupe B $A$. astaci ayant été infectées sont mortes dans les 58 jours suivant l'infection. Les résultats de la reconstitution phylogénétique indiquent que les écrevisses à pinces étroites du lac Jängynjärvi sont étroitement apparentées aux écrevisses à pinces étroites du lac Bolshoye près de Krasnoïe, situé sur l'île de Solovestky dans la mer Blanche, ainsi qu'aux populations de la région de Tioumen, toutes deux en

\footnotetext{
*Corresponding author: japo.jussila@uef.fi
} 
Russie. Cela pourrait confirmer les hypothèses antérieures sur l'introduction en Finlande d'écrevisses à pinces étroites en provenance de Russie ou pourrait indiquer un lien hydrologique antérieur.

Mots clés : Pontastacus leptodactylus / Astacus leptodactylus / peste de l'écrevisse / cytochrome I oxydase

\section{Introduction}

The narrow-clawed crayfish (Pontastacus leptodactylus (Eschscholtz, 1823)) (Crandall and De Grave, 2017) is a native European species, indigenous to the Ponto-Caspian Basin (Souty-Grosset et al., 2006), and currently distributed in 32 countries (Kouba et al., 2014), with the northernmost population been reported from the lake Bolshoye near Krasnoye, located on the White Sea island of Solovestky, Russia (Borovikova et al., 2016). There is scattered information of the narrow-clawed crayfish populations from Finland and it has been claimed to be on its northwesternmost distribution in the lakes in southeastern Finland (SoutyGrosset et al., 2006). It has been reported to have co-existed with the noble crayfish (Astacus astacus) and the signal crayfish (Pacifastacus leniusculus) in the lake Kivijärvi in early 2000s (Mannonen et al., 2002; Jussila and Mannonen, 2004), but was later claimed to have disappeared (Vesa Tiitinen, oral communication). The reasons for the disappearance have not been studied in detail, but Aphanomyces astaci infection, the signal crayfish acting as a vector, or environmental conditions (Larson et al., 2019) could be possible reasons.

Even though there has been numerous attempts to resolve systematic and taxonomy of the narrow-clawed crayfish (Bott, 1950, 1972; Karaman, 1962, 1963; Albrecht, 1982, 1983; Brodsky, 1983; Starobogatov, 1995; Śmietana et al., 2006; Maguire and Dakić, 2011a; Akhan et al., 2014; Maguire et al., 2014), its taxonomical status is still under scrutiny and not fully resolved. Therefore, it is suggested that the narrowclawed crayfish is considered as the Pontastacus leptodactylus (Eschscholtz, 1823) species complex (Kouba et al., 2014; Crandall and De Grave, 2017). Previous research on a large morphometrical data set have shown that Asian populations of the narrow-clawed crayfish differ significantly from European populations (Maguire and Dakić, 2011a). Furthermore, application of mtDNA cytohrome c oxidase subunit 1 (COI) and $16 S$ rRNA markers revealed existence of two well supported phylogroups, one that included populations from Europe (Croatia, Bulgaria, Poland and Turkey), and the other from Asia (Armenia and Russia) (Maguire et al., 2014). Furthermore, Akhan et al. (2014) in their study of genetic structure of Turkish narrow-clawed crayfish populations, using mtDNA COI marker, discovered existence of three distinct clades within populations of this species in Turkey, two congruent with previous findings (Maguire et al., 2014), and a new one, endemic to Turkey.

Compared to other native European species, the narrowclawed crayfish grows larger and is more tolerant to altered ambient conditions (Stucki, 1999; Souty-Grosset et al., 2006). It spreads and colonises new habitats, frequently displacing other native species (Bij de Vaate et al., 2002; Maguire et al., 2011b; Hudina et al., 2016). Also, since it is commercially important, it has been frequently relocated (Bij de Vaate et al., 2002; Harlioğlu, 2004; Kouba et al., 2014). The relationship between $A$. astaci and the narrow-clawed crayfish is complex, as the narrow-clawed crayfish have appeared to be both rather resistant and also obviously susceptible to $A$. astaci infection (e.g., Schikora, 1906; Unestam, 1969; Alderman et al., 1987; Harlioğlu, 2008; Kokko et al., 2018). These features all could be assisting narrow-clawed crayfish in colonising new water bodies and re-establishing productive stocks after severe A. astaci epidemics (e.g., Harlioğlu, 2008).

The narrow-clawed crayfish presence in Finland has an ambiguous status since it has been reported only from the wild in early 2000s (Holdich, 2002; Mannonen et al., 2002; Jussila and Mannonen, 2004), and afterwards only sporadically (laji.fi 2019), and generally it is speculated that it is not naturally distributed in Finland (Skurdal et al., 1999; Holdich et al., 2009; Kouba et al., 2014). Possible explanation for its absence could be extinction caused by $A$. astaci epidemics or introduced invasive signal crayfish. Still, knowing that narrow-clawed crayfish is to a certain extent resistant to A. astaci infections (Kokko et al., 2012, 2018; Schrimpf et al., 2012; Svoboda et al., 2012; Panteleit et al., 2018) and it is capable of coexisting with (Holdich et al., 2009; Pacioglu et al., 2020) or even outcompeting invasive species, e.g., Faxonius (Orconectes) limosus (Rafinesque, 1817) (Laurent, 2003), it is possible that it occures in some waterbodies in low abundance. Furthermore, the latest discovery of the narrowclawed crayfish presence in Finland was accidental, as they were provided as potential noble crayfish stocklings by fishing rights owners during a crayfisheries management project. This indicates that even between such different species as the narrow-clawed crayfish and the noble crayfish the difference can be unrecognisable to the general public.

It has been claimed that the narrow-clawed crayfish could be one of the most robust and potential invasive species, due to its fecundity, large size and possible resistance against A. astaci and other pathogens (e.g., Pârvulescu et al., 2015; Hudina et al., 2016; Salighehzadeh et al., 2019). Narrowclawed crayfish has been reported to outcompete NICS in addition to being able to displacing also ICS (Holdich, 2002; Souty-Grosset et al., 2006; Maguire et al., 2018). Thus it has been widely distributed in Europe and has been, similarly to the noble crayfish, assisted by humans in its spreading. In Finland, the narrow-clawed crayfish is considered an alien species being locally or potentially harmful, to be monitored and also even as a possible target for eradication (Niemivuo-Lahti, 2012).

The aims of this research were to study the properties of this recently discovered Finnish narrow-clawed crayfish population in the lake Jängynjärvi, i.e. its phylogenetic relationship to other European populations and its possible resistance against the $\mathrm{B}$ haplogroup $A$. astaci infection. We also make comparisons to the noble crayfish of Finnish origin in regard to $A$. astaci infection resistance. These aspects would increase understanding of the narrow-clawed crayfish spreading and maybe even allow us to speculate on its status as an alien species in Finland. 
Table 1. The sequence data collected from the barcode of life - database (BOLD) system and the NCBI Genbank for phylogenetic analyses. Sequence length is $484 \mathrm{bp}$, except for those with superscript 1 it is $466 \mathrm{bp}$.

\begin{tabular}{|c|c|c|c|}
\hline Access number & $\begin{array}{l}\text { Species|Analyzed fragment|NCBI GenBank } \\
\text { Access No }\end{array}$ & The country of origin & $\begin{array}{l}\text { No of } \\
\text { sequences }\end{array}$ \\
\hline CBCC029-32-11 & Pontastacus leptodactylus|COI-5P & Armenia & 4 \\
\hline GBCMA10736-38-15 & Pontastacus leptodactylus $|\mathrm{COI}-5 \mathrm{P}| \mathrm{KF} 181938$ & Armenia & 3 \\
\hline GBCMA10743-52-15 & Pontastacus leptodactylus $|\mathrm{COI}-5 \mathrm{P}| \mathrm{KF} 181945$ & Armenia & 10 \\
\hline KX279347.1 & Astacus astacus Aast1 & France & 1 \\
\hline GBCMA10741-42-15 & Pontastacus leptodactylus|COI-5P|KF181943 & Bulgaria & 2 \\
\hline GBCMA10726-35-15 & Pontastacus leptodactylus $|\mathrm{COI}-5 \mathrm{P}| \mathrm{KF} 181928$ & Croatia, Dobra & 10 \\
\hline MF288079-86.1 & Pontastacus leptodactylus & Denmark, Galizer & 6 \\
\hline JÄN2-9 & Pontastacus leptodactylus & Finland, Jängynjärvi & 7 \\
\hline $\begin{array}{l}\text { GBCM5911-17; } \\
\text { GBCM6223-17; } \\
\text { GBCM7384-17; } \\
\text { GBCM9155-17 }\end{array}$ & Pontastacus leptodactylus|COI-5P|KU571459 & Iran, ARAS Dam lake & 1 \\
\hline KU571455.1, $-58.1,-66.1$ & Pontastacus leptodactylus & Iran, ARAS Dam lake & 3 \\
\hline GBCM8520-17 & Pontastacus leptodactylus|COI-5P|KU571460 & Iran, ARAS Dam lake & 1 \\
\hline GBCM6827-17 & Pontastacus leptodactylus $|\mathrm{COI}-5 \mathrm{P}| \mathrm{KP} 704405$ & Russia, lake Bolshoye Krasnoye & 1 \\
\hline GBCMA10739-40-15 & Pontastacus leptodactylus $|\mathrm{COI}-5 \mathrm{P}| \mathrm{KF} 181941$ & Russia, Tyumen & 2 \\
\hline GBCMA10740-15 & Pontastacus leptodactylus $|\mathrm{COI}-5 \mathrm{P}| \mathrm{KF} 181942$ & Russia, Tyumen & 1 \\
\hline DNATR069-12 & Pontastacus leptodactylus|COI-5P|JQ623972 & Turkey & 1 \\
\hline DNATR2240-59-13 & Pontastacus leptodactylus $|\mathrm{COI}-5 \mathrm{P}| \mathrm{KC} 789386$ & Turkey & 20 \\
\hline GBCM5769-17 & Pontastacus leptodactylus|COI-5P|KU571462 & Turkey & $1^{1}$ \\
\hline GBCMA9059-94-14 & Pontastacus leptodactylus|COI-5P|JQ421483 & Turkey & 46 \\
\hline GBCMD7160-77-13 & Pontastacus leptodactylus|COI-5P|JQ421482 & Turkey & 17 \\
\hline GBCMD14156-13 & Pontastacus leptodactylus $|\mathrm{COI}-5 \mathrm{P}| \mathrm{KC} 311416$ & Turkey & 1 \\
\hline
\end{tabular}

\section{Materals and methods}

\subsection{The crayfish for molecular analyses}

The sampling was conducted during autumn 2016, as a part of a crayfish stocking and monitoring program, during which a previously unknown narrow-clawed crayfish population was discovered from one South Karelian destination, lake Jängynjärvi. A total of 12 specimens (three females, eight males and one which could not be sexed due to cannibalism during holding) were collected and transferred to the University of Eastern Finland, Kuopio campus, as frozen. The average size of the crayfish was $11.2 \pm 2.1 \mathrm{~cm}$.

\subsection{Molecular analyses}

The DNA was extracted using the Insect DNA Kit (Zymo Research, Irvine, California, USA). The DNA extractions were conducted from the inner joints of walking legs containing both cuticle and muscle tissue. First, the tissues were disrupted with ceramic beads ( $5 \mathrm{~min}$, full speed) in TissueLyser II (Qiagen, Hilden, DE) in presence of the lysis buffer and the DNA extractions were then made according the manufacturer's protocol. The final elution step was conducted using $50 \mu \mathrm{L}$ of the elution buffer provided in the extraction kit. The DNA concentrations and purities were monitored with Nanodrop ND-1000 spectrophotometer (Thermo Fisher Scientific, Waltham, Massachusetts, USA).

PCR was carried out using the standard primers LCO1490 and $\mathrm{HCO} 2198$ (Folmer et al., 1994) in $25 \mu \mathrm{L}$ reaction volume containing $1 \mathrm{U}$ of DreamTaq DNA polymerase (Thermo Fisher
Scientific, Waltham, Massachusetts, US), $2 \times$ DreamTaq Green master mix (Thermo Fisher Scientific, Waltham, Massachusetts, US), $10 \mathrm{mM}$ of both primers and $70-160 \mathrm{ng}$ of template DNA. The reaction volume was filled with PCR-grade water. The amplification was conducted in PTC-200 thermal cycler (MJ Research) in following conditions: $95^{\circ} \mathrm{C}, 3 \mathrm{~min}, 35 \times$ $\left(95^{\circ} \mathrm{C}, 30 \mathrm{~s} ; 47^{\circ} \mathrm{C}, 45 \mathrm{~s} ; 72^{\circ} \mathrm{C}, 60 \mathrm{~s}\right)$ and $72{ }^{\circ} \mathrm{C}, 10 \mathrm{~min}$. Each set of reactions contained a positive control (crayfish DNA) and a blank reaction without a template (NTC).

The amplification success was checked in $1.5 \%$ agarose gel containing $0.5 \mu \mathrm{M}$ EtBr (Ethidium Bromide) and purified with NucleoSpin PCR Cleanup kit (Macherey Nagel, Düren, DE). The Sanger sequencing reactions were performed in GATC Biotech, Germany, with the primer LCO1490 (Folmer et al., 1994).

\subsection{Data analysis}

The resulting sequence data were manually checked and edited in Geneious version 8.1 (Kearse et al., 2012). A consensus sequence of the observed haplotype was entered into the NCBI GenBank database with access number MN502811. Then, the obtained sequences and the P. leptodactylus COI data available in the Barcode of Life Database (BOLD; Tab. 1) were multiple aligned in Geneious 8.1. The optimal substitution model, $\mathrm{K} 81 \mathrm{uf}+\mathrm{I}+\mathrm{G}$ was determined using JModel Test in Topali v1.5 (Milne et al., 2004) and a maximum likelihood tree was generated with PhyML (Guindon et al., 2010) plugin in Geneious, with 100 bootstrap replicates. Astacus astacus isolate Aast1 COI-sequence (KX279347.1) was selected as an outgroup. 


\subsection{Crayfish in the infection experiment}

Crayfish specimens were obtained from two different sources. The wild noble crayfish (A. astacus) were acquired from a commercial trapper at the lake Rytky $\left(62^{\circ} 51^{\prime} 22^{\prime \prime} \mathrm{N}\right.$, $27^{\circ} 25^{\prime} 06^{\prime \prime} \mathrm{E}$ ) and the narrow-clawed crayfish (P. leptodactylus) were obtained from a commercial trapper at the lake Jängynjärvi $\left(61^{\circ} 1^{\prime} 9^{\prime \prime} \mathrm{N}, 27^{\circ} 57^{\prime} 16^{\prime \prime} \mathrm{E}\right)$.

The lake Rytky noble crayfish population experienced an A. astaci epidemic in the early 1980 s, but recovered with the aid of stockings and is currently producing commercial catches. Since the 1980s there have been no detections of A. astaci carriers in wild lake Rytky stock. The lake Jängynjärvi narrow-clawed crayfish population is the only known population from Finland, while it has been reported previously (Mannonen et al., 2002) that the lake Kivijärvi downstream of the lake Jängynjärvi had a mixed population of the narrow-clawed crayfish, the noble crayfish and the signal crayfish as recently as 2004. Both the lake Rytky noble crayfish and the lake Jängynjärvi narrow-clawed crayfish have been analysed for $A$. astaci infection (2011 and 2017, respectively, unpublished data) and shown to be healthy.

Before the experiment, crayfish were kept in a cool room $\left(+5^{\circ} \mathrm{C}\right)$ for two months. Stocks of different origin were held separate to prevent possible cross infections. All the crayfish were acclimated prior to the experiment for two weeks at the experimental system at room temperature in the filtered lake Kallavesi water. All of the crayfish were healthy mature adults (a total of 22 crayfish of both species; 14 and 12 females among noble crayfish and narrow-clawed crayfish, respectively) and their CL was measured $(\mathrm{mm})$ before being transferred into individual chambers in the experimental system.

\subsection{Experimental design}

The experimental system consisted of individual interconnected $2 \mathrm{~L}$ tanks with recirculating filtered water from the lake Kallavesi, the detailed system design as described by Jussila et al. (2011) and Makkonen et al. (2019) at a flow rate that ensured full turnover of the $2 \mathrm{~L}$ tanks every hour. The system contamination by $A$. astaci was prevented by filtration using set up described by Jussila et al. (2013). The filtration was to ensure that the $A$. astaci zoospores would be removed from the recirculating water so that the original challenge doses would be the sole source of the $A$. astaci infections. The crayfish were given sweet corn kernels (two each, Rainbow ${ }^{\circledR}$ ) as food every second day. The experimental system was monitored daily and notes on crayfish behaviour, moults, mortalities and other relevant features were made. Water quality (DO-\%, pH, conductivity and temperature) was measured twice a week (WTW Multi 3430 meter). The sizes of the experimental groups were either 7 or 8 individual crayfish.

The day and night rhythm were 12 hours with lights on (fluorescent lights) and 12 off. The water temperature was kept stable by room air conditioning at $18 \pm 1{ }^{\circ} \mathrm{C}$. Gravel containing calcium was added to the sump tanks to maintain the $\mathrm{pH}$ close to the optimum of $\mathrm{pH} 7$ in the recirculating water. Water quality parameters remained within the optimal ranges for crayfish throughout the study. The dissolved oxygen (DO-\%) was $97.9 \pm$ $2.0 \%(\min -\max , 91.0-100.2 \%), \mathrm{pH}$ was $7.4 \pm 0.4(\min -\max$,
6.5-7.7), conductivity $209.3 \pm 4.1 \mu \mathrm{S} / \mathrm{cm} \quad$ (min-max, $205-220 \mu \mathrm{S} / \mathrm{cm})$ and water temperature was $19.0 \pm 1.0^{\circ} \mathrm{C}$ (min-max, $15.5-21.0^{\circ} \mathrm{C}$ ).

\subsection{Aphanomyces astaci isolates, production of the zoospores and the challenge}

We used PsI-Tahoe (UEF T16B, B haplogroup) and PsIPuujärvi (UEF8866-2, B haplogroup) isolates from signal crayfish (Makkonen et al., 2011, 2012a,b, 2014) to infect the experimental crayfish. Both isolates have been reported to be very virulent (Jussila et al., 2013b; Makkonen et al., 2019) and thus a good candidate for $A$. astaci isolate virulence comparisons. Both of these isolates had been isolated by the University of Eastern Finland crayfish research group and then maintained on PG1-agar (Unestam, 1965).

Details of the methods for zoospore production, modified after Cerenius et al. (1988), are explained in Makkonen et al. (2012b). The challenge dose for the infection groups was 1000 zoospores $\mathrm{mL}^{-1}$ for each individual $2 \mathrm{~L}$ tank. The spore dosage was released to bottom of each tank using graduated pipettes. Before administration of the spores, the water circulation was closed and then opened again $9 \mathrm{~h}$ post spore administration to prevent the dilution of the dosage.

\subsection{Aphanomyces astaci status of the crayfish}

The tissue sample analysed was a combined from three different tissues, containing a piece of abdominal cuticle, joint of walking leg and partial uropod. The DNA was extracted from 12 specimens. The presence and the amount of $A$. astaci DNA in each sample was analysed by real-time qPCR in two replicates of non-diluted and $10 \times$ diluted samples according to Vrålstad et al. (2009) with LightCycler 480 II qPCR machine (Roche, Switzerland) in $10 \mu \mathrm{L}$ reaction volume.

The amount of $A$. astaci DNA present in the analysed tissue was converted into agent levels (Vrålstad et al., 2009) as follows: agent level A0 (0 PFU) and A1 (PFUobs $<5$ PFU) are considered uninfected and agent level A2 (5 PFU $\leq$ PFUobs $<$ $50 \mathrm{PFU})$ and higher (A3: 50 PFU $\leq$ PFUobs $<10^{3}$ PFU; A4: $10^{3} \mathrm{PFU} \leq$ PFUobs $<10^{4} \mathrm{PFU} ; \mathrm{A} 5: 10^{4} \mathrm{PFU} \leq$ PFUobs $<10^{5}$ PFU; A6: $10^{5} \mathrm{PFU} \leq$ PFUobs $<10^{6} \mathrm{PFU}$; A7: $10^{6} \mathrm{PFU} \leq$ ) are considered infected with $A$. astaci.

\subsection{Statistics}

The statistical package used was SPSS v.21 and the statistical differences related to $A$. astaci challenge mortality were estimated using Kaplan-Meier (Log-Rank) survival analyses with criteria for the statistically significant difference being $p<0.05$. AV Bio-Statistics 4.9 Professional was used for binomial probability estimation. The means are expressed as mean \pm SD.

\section{Results}

\subsection{Genetics}

The seven sequenced $P$. leptodactylus individuals from the lake Jängynjärvi all had an identical haplotype, i.e. no differences between the sequences were observed. The 
haplotype was unique, as none of the sequences available in BOLD or Genbank databases were $100 \%$ identical with the Finnish one. However, according to the phylogenetic analyses, the Finnish specimens grouped with the Russian sequences (Fig. 1). The closest match was the individual from the lake Bolshoye in Krasnoye, which, although had a shorther COI sequence fragment available, shared $99.8 \%$ identity (i.e. one nucleotide difference) on the shared $C O I$-sequence fragment of approximately 300 bp's.

\subsection{Aphanomyces astaci status of the crayfish from lake Jängynjärvi}

The analysed individuals $(n=12)$ showed no signs of A. astaci infection, i.e. no A. astaci DNA was detected in them. Because of nature of the $A$. astaci analyses, this only shows that the analysed crayfish were not infected at time when they were sampled. Furthermore, due to small sample size, there would still be a $95 \%$ confidence level probability for the background population itself to be infected at a prevalence of 0-26.5\% (binomial probability, AV Bio-Statistics 4.9 Professional).

\subsection{Aphanomyes astaci challenge}

In the infection experiment, we observed a statistically significant difference in the average day of death (Tab. 2) and cumulative death rate (Fig. 2) in both species among different A. astaci $\mathrm{B}$ haplogroup challenges and control treatments, with B haplogroup $A$. astaci from lake Tahoe being more virulent. There was also a significant difference between crayfish species when challenged with same $A$. astaci isolate (Tab. 3), with the lake Rytky noble crayfish having a faster mortality rate than lake Jängynjärvi narrow-clawed crayfish in both challenged B haplogroup $A$. astaci groups. In the B haplogroup A. astaci challenged groups all crayfish died (Fig. 2), while all except one control group crayfish survived up to 65 days.

\section{Discussion}

Our data shows that the lake Jängynjärvi narrow-clawed crayfish population, which was detected for the first time in 2016 , is closely related to two populations of Russian origin. The obtained results direct toward speculations that the scattered and few Finnish narrow-clawed crayfish populations could have spread from the east, either after last ice age through common waters or later by manmade introductions or both. Further sampling and analyses of Finnish $P$. leptodactylus populations may help revealing their connection to other European populations. We also discovered that the laboratory challenged Finnish narrow-clawed crayfish were more resistant against PsI-Puujärvi and PsI-Tahoe $A$. astaci isolates, both B haplogroup, compared to the Finnish noble crayfish. This bearing in mind, that all challenged crayfish died within two months. Thus, the elevated resistance, even though being statistically significant, would most probably be too weak to allow the persistance of this narrow-clawed crayfish population during acute $A$. astaci $\mathrm{B}$ haplogroup epidemics.

Currently, the narrow-clawed crayfish is considered an alien species in Finland due to its suspected recent spreading to
Table 2. The average day of death during the infection challenge experiment (mean $\pm \mathrm{SD}$ ). The data analysed using Kaplan-Meier LogRank (Mantel-Cox) $\chi^{2}$. The superscripts indicate statistical differences, letters within a row and numbers within a column. $A$. astaci challenge in question indicated as genotype and origin.

\begin{tabular}{llll}
\hline & $\begin{array}{l}\text { A. astaci } \\
\text { PsI-Tahoe }\end{array}$ & $\begin{array}{l}\text { A. astaci } \\
\text { PsI-Puujärvi }\end{array}$ & Control \\
\hline $\begin{array}{l}\text { narrow-clawed } \\
\text { crayfish } \\
\text { noble crayfish }\end{array}$ & $15.9 \pm 1.3^{\mathrm{a} 1}$ & $34.0 \pm 6.4^{\mathrm{b} 1}$ & $62.9 \pm 2.1^{\mathrm{c} 1}$ \\
\hline
\end{tabular}

the Finnish waters (Niemivuo-Lahti, 2012), but there seems to be less interest in prevention of its spread or eradication from the sites where it exists. On the other hand, the few remaining populations in Finland could be eradicated if there would be sufficient resources for successfull eradication. It has been speculated that the possible spreading of the narrow-clawed crayfish to southeastern parts of Finland was from Russia (Skurdal et al., 1999; Holdich, 2002), supported by reports that the narrow-clawed crayfish have been detected over last few decades in a few water bodies close to the Russian border (Mannonen et al., 2002; Jussila and Mannonen, 2004; Popov, 2016; Laji.fi, 2019). In the present research those speculations were corraborated by the results from molecular phylogenetic analyses (Fig. 1). The COI sequences from the lake Jängynjärvi narrow-clawed crayfish population grouped with sequences from the lake Bolshoye Krasnoye (Russia, approx. $590 \mathrm{~km}$ distance and no obvious water system connection) and the Tyumen region (Russia, approx. $2200 \mathrm{~km}$ distance and no obvious water system connection). Those sequences, along with other sequences from Turkish, Iranian and Armenian populations belong to phylogroup Asia sensu Maguire et al. (2014) or clade II sensu Akhan et al. (2014). Either naturally spread or introduced by humans, this population, according to our knowledge, is the westernmost positioned representative of the Asian clade or clade II narrow-clawed crayfish (Fig. 1). It has been speculated that the narrow-clawed crayfish has been spreading in the western parts of Russia either using manmade channels connecting water bodies or by the general public making introductions (Borovikova et al., 2016; Popov, 2016).

Our study showed, that the lake Jängynjärvi narrowclawed crayfish population has a higher resistance against A. astaci $\mathrm{B}$ haplogroup infection compared to the noble crayfish from the lake Rytky, adding to speculations of its elevated disease resistance (e.g., Pacioglu et al., 2020). It has to be emphasised that all the $A$. astaci challenged narrow-clawed crayfish died within 60 days in our study. Previously, it has been reported that the narrow-clawed crayfish could be susceptible to the A. astaci infection (e.g., Schikora 1906; Alderman et al., 1987), while some reports indicate that there might be an elevated resistance against the $A$. astaci infection and resulting higher survival rate during epidemics (e.g., Unestam, 1969; Kokko et al., 2012, 2018; Svoboda et al., 2012, 2014). Several currently productive narrow-clawed crayfish populations have been reported as chronic $A$. astaci carriers in recent studies (Kokko et al., 2012, 2018; Schrimpf et al., 2012; Svoboda et al., 2012, 2014; Panteleit et al., 2018; 
J. Jussila et al.: Knowl. Manag. Aquat. Ecosyst. 2020, 421, 30

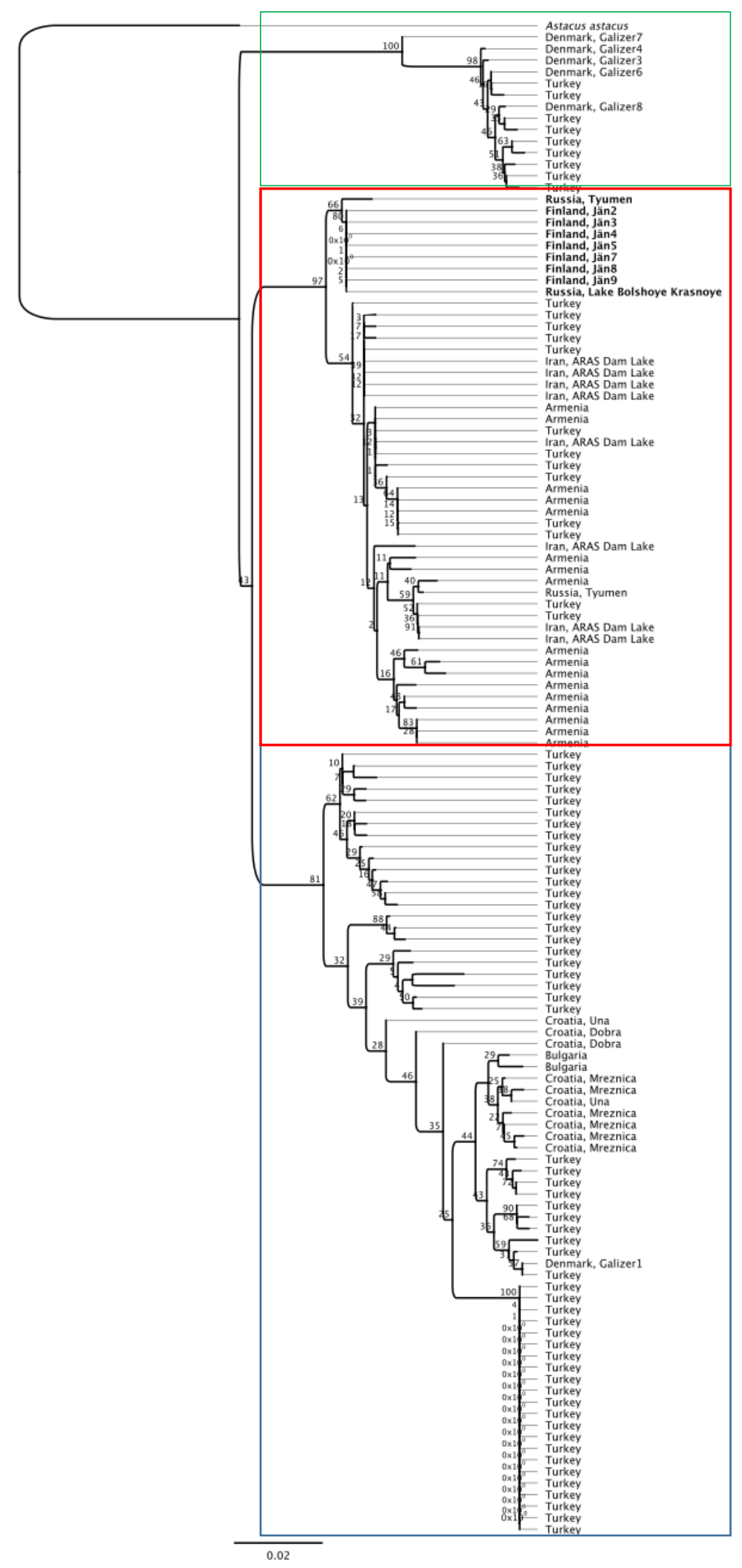

Clade 3 sensu Akhan et al. 2014

Phylogroup Asia sensu Maguire et al. 2014/ Clade 2 sensu Akhan et al. 2014

Phylogroup Europe sensu Maguire et al. 2014/ Clade 1 sensu Akhan et al. 2014

Fig. 1. Maximum likelihood tree of cytochrome I oxidase sequences (Geneious) of the Finnish P. leptodactylus (in bold with closely related ones) and related sequences available in GenBank. Also, phylogroup afiliation sensu Maguire et al. (2014) and Akhan et al. (2014) are given. 
Table 3. The $\chi^{2}$ values for the Kaplan-Meier Log-Rank (Mantel-Cox) for average day of death among the treatment groups with statistical differences expressed as ns $=$ non significant, $*=\mathrm{p}<0.05,{ }^{*}=\mathrm{p}<0.01$ and $* * *=\mathrm{p}<0.001$. Groups indicated as species and $\mathrm{A}$. astaci challenge strain in question. Number of crayfish per experimental group in brackets after the group definition in the first column.

\begin{tabular}{lllll}
$\begin{array}{l}\text { narrow-clawed } \\
\text { crayfish, }\end{array}$ & $\begin{array}{l}\text { narrow-clawed } \\
\text { crayfish, }\end{array}$ & $\begin{array}{l}\text { narrow-clawed } \\
\text { crayfish, }\end{array}$ & $\begin{array}{l}\text { noble } \\
\text { crayfish, }\end{array}$ & $\begin{array}{l}\text { noble } \\
\text { crayfish, }\end{array}$ \\
PsI-Tahoe & PsI-Puujärvi & Control & PsI-Tahoe & PsI-Puujärvi \\
\hline
\end{tabular}

narrow-clawed crayfish, PsI-Tahoe (8)

narrow-clawed crayfish, PsI-Puujärvi (7)

narrow-clawed crayfish, Ctrl (7)

noble crayfish, PsI-Tahoe (8)

noble crayfish, Ps-Puujärvi (7)

noble crayfish, Ctrl (7)

$7.3^{* *}$
$15.0^{* * *}$
$15.8^{* * *}$
$0.0^{\mathrm{ns}}$
$15.0^{* * *}$

$11.4^{* * *}$
$14.3^{* * *}$
$7.2^{* *}$
$14.8^{* * *}$

$15.0^{* * *}$
$14.5^{* * *}$
$1.0^{\text {ns }}$ $0.0^{\mathrm{ns}}$

$15.0^{* * *}$

$14.5^{* * *}$

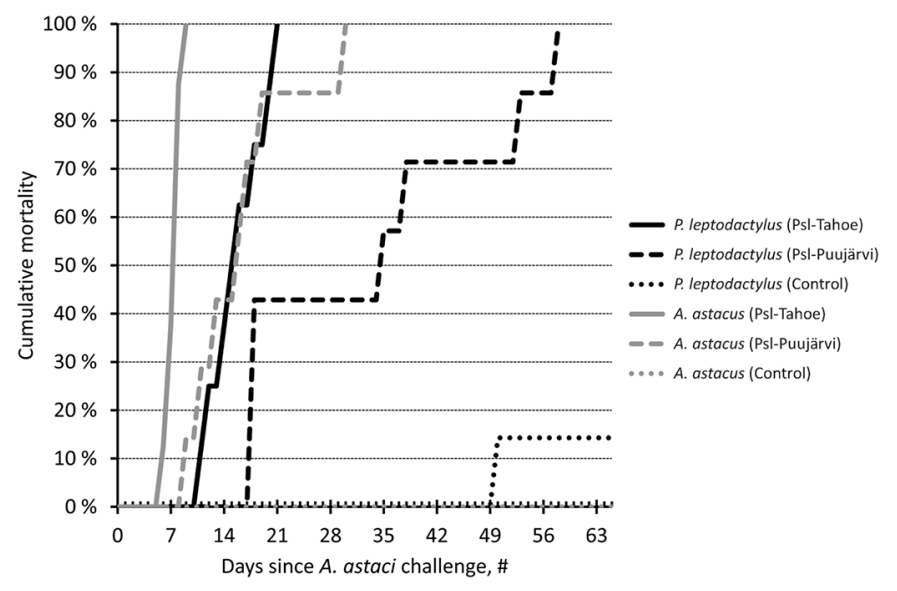

Fig. 2. Cumulative mortality of the narrow-clawed crayfish and the noble crayfish after challenged with two different PsI genotype (B haplogroup) A. astaci isolates. Experimental group size was 7 crayfish, except 8 crayfish in the PsI-Tahoe $A$. astaci challenged groups.

Pacioglu et al., 2020), also indicating elevated resistance against $A$. astaci infection.

The speculated narrow-clawed crayfish resistance against A. astaci infection (Schikora, 1906; Unestam, 1969; Alderman et al., 1987; Kokko et al., 2012, 2018; Svoboda et al., 2012, 2014, 2017, Pacioglu et al., 2020) could be a result of different environmental conditions during the $A$. astaci infections or differences in the resistance of different narrow-clawed crayfish stocks from different geographical origins (e.g., Mitchell and Read, 2005; Mydlarz et al., 2006; Jussila et al., 2014; Panteleit et al., 2018; Larson et al., 2019; Pacioglu et al., 2020). It could also be stated that the possible resistance against the $A$. astaci infection could have resulted from selection of the most fit individuals during epidemics or even variable virulence of the infecting $A$. astaci strain (e.g., Kokko et al., 2012, 2018; Jussila et al., 2013, 2014). So far, most of the evidence on the narrow-clawed crayfish $A$. astaci resistance have been based on observations obtained from wild population epidemics (e.g., Kokko et al., 2018). Furthermore, one of the aspects regarding further mixing of the narrowclawed crayfish populations during translocations could be hybridisation and possibility of even more invasive capacity, e.g. elevated disease resistance, among those narrow-clawed crayfish stocks (Arcella et al., 2014).

It has been shown in other parts of Europe, that the narrow-clawed crayfish can be a permanent carrier of A. astaci, both A haplogroup and B haplogroup strains (Kokko et al., 2012, 2018; Svoboda et al., 2012, 2014, 2017). The narrow-clawed crayfish population studied here has so far been proven healthy, although the number of studied specimen for the $A$. astaci infection remains low. This allows still a possibility, that the lake Jängynjärvi population itself could be $A$. astaci infected but the prevalance might be low, less than $27 \%$. This, together with the observed slightly higher $A$. astaci resistance among tested lake Jängynjärvi narrow-clawed crayfish, emphasises the fact that one should not attempt to spread this population further, as there is a chance to spread also $A$. astaci with the crayfish. Furthermore, detailed investigations into the health status and disease resistance should be carried out among the lake Jängynjärvi narrow-clawed crayfish.

The narrow-clawed crayfish population from the lake Jängynjärvi is within the same water system where the noble crayfish, the signal crayfish and the narrow-clawed crayfish have co-existed early in the 2000 s, e.g., in the lake Kivijärvi (Mannonen et al., 2002; Jussila and Mannonen, 2004), which lies only a few kilometers downstream of the lake Jängynjärvi. Since then neither noble crayfish nor narrow-clawed crayfish have been detected for several years (Vesa Tiitinen, oral communication), while there is a report of the narrow-clawed crayfish in one of the remote bays of the lake Kivijärvi from year 2011 (laji.fi, 2019). It remains to be studied, what is the health status of this particular narrow-clawed crayfish subpopulation and whether it still exists.

We have shown that the recently discovered narrowclawed crayfish population from the lake Jängynjärvi in Finland is significantly more resistant against $A$. astaci infection compared to a Finnish noble crayfish population. We also showed that there is a close genetic resemblance to Russian narrow-clawed crayfish populations, verifying speculations on the spreading pathway of the narrow-clawed crayfish to Finland. Being an alien and rare species in Finland, the narrow-clawed crayfish has so far raised very less attention, but it should be taken into account that further spreading of this 
species would pose a threat to the remaining Finnish noble crayfish stocks.

Acknowledgements. We are thankful to the South Karelian crayfisherpersons for their cunning detection of the remaining narrow-clawed crayfish in Finland and Mr. Adam P. Maguire (Zagreb, Croatia) for the English language editing.

\section{References}

Akhan S, Bektas Y, Berber S, Kalayci G. 2014. Population structure and genetic analysis of narrow-clawed crayfish (Astacus leptodactylus) populations in Turkey. Genetica 142: 381-395.

Albrecht H. 1982. Das System der europäischen Flusskrebse (Decapoda, Astacidae): Vorschlag und Begründung. Mitt Hamb Zool Mus Inst 79: 187-210.

Albrecht H. 1983. Besiedlungsgeschichte und ursprünglich holozäne Verbreitung der europäischen Flusskrebe. Spixiana 6: 61-77.

Alderman DJ, Polglase JL, Frayling M. 1987. Aphanomyces astaci pathogenicity under laboratory and field conditions. J. Fish Dis 10: 385-393.

Arcella TE, Perry WL, Lodge DM, Feder JL. 2014. The role of hybridization in a species invasion and extirpation of resident fauna: Hybrid vigor and breakdown in the rusty crayfish, Orconectes rusticus. J Crust Biol 34: 157-164.

Bij de Vaate A, Jazdzewski K, Ketelaars HA, Gollasch S, Van der Velde G. 2002. Geographical patterns in range extension of PontoCaspian macroinvertebrate species in Europe. Can J Fish Aquat Sci 59: 1159-1174.

Borovikova EA, Alekseeva JA, Bagirov NE, Makhrov AA, Popov IY 2016. Genetic identification of a crayfish (Astacus) species at the northern edge of their distribution area (Solovetsky Islands, White Sea). Biochem Syst Ecol 65: 205-208.

Bott R. 1950. Die Flusskrebse Europas (Decapoda, Astacidae). Proc Senck Nat Soc 483: 1-36.

Bott R. 1972. Besiedlungsgeschichte und systematik der Astacieden West-Europas unter besonderer beruchksichtigung der schweiz. Rev Suisse Zool 79: 387-408.

Brodsky SYa. 1983. On the systematics of Palaearctic crayfishes (Crustacea, Astacidae). Freshw Crayfish 5: 464-470.

Cerenius L, Söderhäll K, Persson M, Ajaxon R. 1988. The crayfish plague fungus, Aphanomyces astaci: diagnosis, isolation and pathobiology. Freshw Crayfish 7: 131-144.

Crandall KA, De Grave S. 2017. An updated classification of the freshwater crayfishes (Decapoda: Astacidea) of the world, with a complete species list. J Crust Biol 37: 615-653.

Folmer O, Black M, Hoeh W, Lutz R, Vrijenhoek R. 1994. DNA primers for amplification of mitochondrial cytochrome $\mathrm{c}$ oxidase subunit I from diverse metazoan invertebrates. Mol Mar Biol Biotechnol 3: 294-299.

Guindon S, Dufayard JF, Lefort V, Anisimova M, Hordijk W, Gascuel O. 2010. New algorithms and methods to estimate maximumlikelihood phylogenies: assessing the performance of PhyML 3.0. Syst Biol 59: 307-321.

Harlioğlu MM. 2004. The present situation of freshwater crayfish, Astacus leptodactylus (Eschscholtz, 1823) in Turkey. Aquaculture 230: 181-187.

Harlioğlu MM. 2008. The harvest of the freshwater crayfish Astacus leptodactylus Eschscholtz in Turkey: harvest history, impact of crayfish plague, and present distribution of harvested populations. Aquacult Int 16: 351-360.
Holdich DM. 2002. Distribution of crayfish in Europe and some adjoining countries. B Fr Pêche Piscic 367: 611-650.

Holdich DM, Reynolds JD, Souty-Grosset C, Sibley PJ. 2009. A review of the ever increasing threat to European crayfish from non-indigenous crayfish species. Knowl Manag Aquat Ecol 394-395: 11.

Hudina S, Hock K, Radović A, Klobučar G, Petković J, Jelić M, Maguire I. 2016. Species-specific differences in dynamics of agonistic interactions may contribute to the competitive advantage of the invasive signal crayfish (Pacifastacus leniusculus) over the native narrow-clawed crayfish (Astacus leptodactylus). Mar Freshw Behav Phys 49: 147-157.

Jussila J, Mannonen A. 2004. Crayfisheries in Finland, a short overview. B Fr Pêche Piscic 372-373: 263-273.

Jussila J, Makkonen J, Kokko H. 2011. Peracetic acid (PAA) treatment is an effective disinfectant against crayfish plague (Aphanomyces astaci) spores in aquaculture. Aquaculture 320: $37-42$.

Jussila J, Kokko H, Kortet R, Makkonen J. 2013. Aphanomyces astaci PsI-genotype isolates from different Finnish signal crayfish stocks show variation in their virulence but still kill fast. Knowl Manag Aquat Ecol 411: 10.

Jussila J, Makkonen J, Vainikka A, Kortet R, Kokko H. 2014. Crayfish plague dilemma: how to be a courteous killer. Boreal Environ Res 19: 235-244.

Karaman MS. 1962. Ein Beitrag zur Systematic der Astacidae (Decapoda). Crustaceana 3: 173-191.

Karaman MS. 1963. Studie der Astacidae (Crustacea, Decapoda) II. Teil. Hydrobiologia 22: 111-132.

Kearse M, Moir R, Wilson A, Stones-Havas S, Cheung M, Sturrock S, Buxton S, Cooper A, Markowitz S, Thierer CDT, Ashton B, Meintjes P, Drummond A. 2012. Geneious Basic: an integrated and extendable desktop software platform for the organization and analysis of sequence data. Bioinformatics 28: 1647-1649.

Kokko H, Koistinen L, Harlioğlu MM, Makkonen J, Aydın H, Jussila J. 2012. Recovering Turkish narrow clawed crayfish (Astacus leptodactylus) populations carry Aphanomyces astaci. Knowl Manag Aquat Ecol 404: 12.

Kokko H, Harlioğlu MM, Aydin H, Makkonen J, Gökmen G, Aksu Ö, Jussila J. 2018. Observations of crayfish plague infections in commercially important narrow-clawed crayfish populations in Turkey. Knowl Manag Aquat Ecol 419: 10.

Kouba A, Petrusek A, Kozák P. 2014. Continental-wide distribution of crayfish species in Europe: update and maps. Knowl Manag Aquat Ecol 413: 05.

Laji.fi 2019: Kapeasaksirapu (narrow-clawed crayfish). https:/laji.fi/ observation/map?target=MX.53033. Visited 28.6.2020 (In Finnish)

Larson ER, Kreps TA, Peters B, Peters JA, Lodge DM. 2019. Habitat explains patterns of population decline for an invasive crayfish. Ecology 100: e02659.

Maguire I, Dakić L. 2011a. Comparative analyses of Astacus leptodactylus morphological characteristics from Croatia and Armenia. Biologia 66: 491-498.

Maguire I, Jelić M, Klobučar G. 2011b. Update on the distribution of freshwater crayfish in Croatia. Knowl Manag Aquat Ecol 401: 31.

Maguire I, Podnar M, Jelić M, Štambuk A, Schrimpf A, Schulz H, Klobučar G. 2014. Two distinct evolutionary lineages of the Astacus leptodactylus species-complex (Decapoda: Astacidae) inferred by phylogenetic analyses. Invertebr Syst 28: 117-123.

Maguire I, Klobučar G, Žganec K, Jelić M, Lucić A, Hudina S. 2018. Recent changes in distribution pattern of freshwater crayfish in Croatia - threats and perspectives. Knowl Manag Aquat Ecol 419: 2. 
Makkonen J, Jussila J, Henttonen P, Kokko H. 2011. Genetic variation in the ribosomal internal transcribed spacers of Aphanomyces astaci Schikora from Finland. Aquaculture 311: $48-53$.

Makkonen J, Jussila J, Kortet R, Vainikka A, Kokko H. 2012a. Differing virulence of Aphanomyces astaci isolates and elevated resistance of noble crayfish Astacus astacus against crayfish plague. Dis Aquat Organ 102: 129-136.

Makkonen J, Jussila J, Kokko H. 2012b. The diversity of the pathogenic oomycete (Aphanomyces astaci) chitinase genes within the genotypes indicate adaptation to its hosts. Fungal Gen Biol 49: 635-642.

Makkonen J, Kokko H, Vainikka A, Kortet R, Jussila J. 2014. Dose-dependent mortality of the noble crayfish (Astacus astacus) to different strains of the crayfish plague (Aphanomyces astaci). J Invertebr Pathol 115: 86-91.

Makkonen J, Kokko H, Gökmen G, Ward J, Umek J, Kortet R, Petrusek A, Jussila J. 2019. The signal crayfish (Pacifastacus leniusculus) in Lake Tahoe (USA) hosts multiple Aphanomyces species. J Invertebr Pathol 166: 107218.

Mannonen A, Jussila J, Siiropää M. 2002. Kapeasaksirapuja Luumäen Kivijärvessä. Suomen kalastuslehti 109: 4-6. In Finnish.

Milne I, Wright F, Rowe G, Marshall DF, Husmeier D, McGuire G. 2004. TOPALi: software for automatic identification of recombinant sequences within DNA multiple alignments. Bioinformatics 20: 1806-1807.

Mitchell SE, Read AF. 2005. Poor maternal environment enhances offspring disease resistance in an invertebrate. Proc Royal Soc B Biol Sci 272: 2601-2607.

Mydlarz LD, Jones LE, Harvell CD. 2006. Innate immunity, environmental drivers, and disease ecology of marine and freshwater invertebrates. Annu Rev Ecol Evol Syst 37: 251-288.

Niemivuo-Lahti J. 2012. Finland's National Strategy on Invasive Alien Species, Ministry of Agriculture and Forestry in Finland, Helsinki, 126 p.

Pacioglu O, Theissinger K, Alexa A, Samoilă C, Sîrbu OI, Schrimpf A, Zubrod JP, Schulz R, Pîrvu M, Lele SF, Jones JI, Pârvulescu L. 2020. Multifaceted implications of the competition between native and invasive crayfish: a glimmer of hope for the native's long-term survival. Biol Inv 22.

Panteleit J, Keller NS, Diéguez-Uribeondo J, Makkonen J, MartínTorrijos L, Patrulea V, Pîrvu M, Preda C, Schrimpf A, Pârvulescu L. 2018. Hidden sites in the distribution of the crayfish plague pathogen Aphanomyces astaci in Eastern Europe: relicts of genetic groups from older outbreaks. J Invertebr Pathol 157: $117-124$.

Pârvulescu L, Pîrvu M, Moroșan LG, Zaharia C. 2015. Plasticity in fecundity highlights the females' importance in the spiny-cheek crayfish invasion mechanism. Zoology 118: 424-432.

Popov I. 2016. Role of the Russian Section of the Gulf of Finland and Its Basin in the Ecosystems of the Baltic Sea. In: Mills A, ed. Baltic and Black Sea: Ecological Perspectives, Biodiversity and Management, Nova Science Publishers. 1-22 pp.

Salighehzadeh R, Sharifiyazdi H, Akhlaghi M, Khalafian M, Gholamhosseini A, Soltanian S. 2019. Molecular and clinical evidence of Aeromonas hydrophila and Fusarium solani co-infection in narrow-clawed crayfish Astacus leptodactylus. Dis Aquat Organ 132: 135-141.

Schikora F. 1906. Die Krebspest. Fischerei-Zeitung 9: 529-532.

Schrimpf A, Pârvulescu L, Copilas-Ciocianu D, Petrusek A, Schulz R. 2012. Crayfish plague pathogen detected in the Danube Delta a potential threat to freshwater biodiversity in southeastern Europe. Aquat Invasions 7.

Skurdal J, Taugbøl T, Burba A, Edsman L, Söderbäck B, Styrishavne B, Tuusti J, Westman K. 1999. Crayfish introductions in the Nordic and Baltic countries. In: F.R. Schram, ed. Crayfish in Europe as alien species. How to make the best out of a bad situation. A.A. Balkema, Rotterdam, 193-220 pp.

Śmietana P, Schulz HK, Keszka S, Schulz R. 2006. A proposal for accepting Pontastacus as a genus of European crayfish within the family Astacidae based on a revision of the West and East European taxonomic literature. Bull Fr Peche Piscic 380-381: 1041-1052.

Souty-Grosset C, Holdich D, Noël P, Reynolds J, Haffner P. 2006. Atlas of crayfish in Europe, Muséum National d'Histoire Naturelle, Paris, 187 p.

Starobogatov YaI. 1995. Taxonomy and geographical distribution of crayfishes of Asia and East Europe (Crustacea Decapoda Astacoidei). Arthropoda Selecta 4: 3-25.

Stucki TP. 1999. Life cycle and life history of Astacus leptodactylus in Chatzensee Pond (Zürich) and Lake Ageri, Switzerland. Freshw Crayf 12: 430-448.

Svoboda J, Kozubíková E, Kozák P, Kouba A, Koca SB, Diler Ö, Diler I, Policar T, Petrusek A. 2012. PCR detection of the crayfish plague pathogen in narrow-clawed crayfish inhabiting Lake Eğirdir in Turkey. Dis Aquat Organ 98: 255-259.

Svoboda J, Strand DA, Vrålstad T, Grandjean F, Edsman L, Kozák P, Kouba A, Fristad RF, Koca SB, Petrusek A. 2014. The crayfish plague pathogen can infect freshwater-inhabiting crabs. Freshw Biol 59: 918-929.

Svoboda J, Mrugała A, Kozubíková-Balcarová E, Petrusek A. 2017. Hosts and transmission of the crayfish plague pathogen Aphanomyces astaci: a review. J Fish Dis 40: 127-140.

Unestam T. 1965. Studies on the crayfish plague fungus Aphanomyces astaci I. Some factors affecting growth in vitro. Physiol Plantarum 18: 483-505.

Unestam T. 1969. Resistance to the crayfish plague in some American, Japanese and European crayfishes. Rep Inst Freshw Res Drottn 49: 202-209.

Vrålstad T, Knutsen AK, Tengs T, Holst-Jensen A. 2009. A quantitative TaqMan ${ }^{\mathbb{B}}$ MGB real-time polymerase chain reaction based assay for detection of the causative agent of crayfish plague Aphanomyces astaci. Vet Microb 137: 146-155.

Cite this article as: Jussila J, Maguire I, Kokko H, Tiitinen V, Makkonen J. 2020. Narrow-clawed crayfish in Finland: Aphanomyces astaci resistance and genetic relationship to other selected European and Asian populations. Knowl. Manag. Aquat. Ecosyst., $421,30$. 